\section{Plant Density and Genotype Effects on Wild Asparagus (Asparagus acutifolius L.) Spear Yield and Quality}

\author{
Paolo Benincasa ${ }^{1}$ and Francesco Tei \\ Dipartimento di Scienze Agrarie ed Ambientali, Università di Perugia, Borgo \\ XX Giugno, 74-06121 Perugia, Italy
}

\section{Adolfo Rosati \\ CRA-Istituto Sperimentale per l'Olivicoltura, sezione di Spoleto (PG), Italy}

Additional index words. Asparagus acutifolius, wild asparagus, plant density, yield, spear, quality

\begin{abstract}
Wild asparagus (Asparagus acutifolius L.) is becoming an interesting niche crop for marginal areas in Europe, but little information is available regarding cultivation techniques, which differ from those of cultivated asparagus (A. officinalis). We experimented with the cultivation of wild asparagus using two different ecotypes planted at two plant densities. We measured yield and number of spears per hectare and spear quality (average weight, portion of edible part, diameter, and dry matter content). There were no significant effects of either genotype or density on the spear yield and number per hectare. No differences among treatments were found on spear quality parameters. Spear yield and number per plant decreased proportionally with increasing plant density, resulting in constant spear yield and number per hectare. Harvest efficiency was $\approx 1.2 \mathrm{~kg}$ of spears per hour of labor when the prickly evergreen vegetation was not removed before harvest and $\approx 3 \mathrm{~kg}$ per hour when the vegetation was cut and removed. In the latter case, harvest would cost approximately one-third of the gross income of the crop suggesting that the crop could easily be economically viable. Further studies are needed to assess whether cutting the vegetation affects plant vigor and longevity in the following years, but also to further study suitable techniques for crop cultivation, especially weed control.
\end{abstract}

The market for some of the most conventional agricultural crops is becoming increasingly unprofitable in developed countries and many farmers have been developing alternative crops for niche markets. Among these are new crops, which include cultivation of plants already known and traditionally used for food but not previously cultivated. One such crop is a wild asparagus species (Asparagus acutifolius L.) known and probably cultivated in ancient times (Aliotta et al., 2004) but not cultivated in modern times until very recently (Rosati, 2001). This species is one of the eight wild asparagus species present in Italy (Bozzini, 1959) and has always been enjoyed in traditional cooking in the Mediterranean area (Adam, 2004; Della et al., 2006; Fiori et al., 2001; Pieroni, 2005; Rosati, 2001; Venezia et al., 1993). The spears are gathered from plants grown in the wild and sold in local markets. Given the high price of these spears, recently some farmers have attempted to cultivate this

\footnotetext{
Received for publication 13 Dec. 2006. Accepted for publication 26 Feb. 2007.

We gratefully acknowledge Mr. Daniele Luchetti, Dr. Catia Beccafichi, and Mr. Andrea Vece for their help in managing the trial and collecting data, and Dr. Darcy Gordon for assistance with the English language.

${ }^{1}$ To whom reprint requests should be addressed; e-mail paoloben@unipg.it
}

tive strategy for market crops. The spears of wild asparagus are smaller than those of A. officinalis and the crown, although large, does not rise with time so planting must not be as deep as with the cultivated asparagus. The frugality of the wild asparagus, currently cultivated using seeds from local, nonselected wild plants, allows for a crop virtually free of pests and diseases, perfectly suited for organic or any other natural farming techniques. The market for wild asparagus exists already, at least in Mediterranean countries (Adam, 2004; Rosati, 2001). Cultivation may supply this market that, up to now, has been limited by the availability of produce from the wild.

It is worth noting that the wild asparagus found in some countries, such as the United States, is the $A$. officinalis escaped from cultivation and not the wild asparagus described here. The two species differ not only botanically and in ecophysiological requirements, but also in their use; $A$. officinalis is used as a vegetable and therefore consumed in large quantities, whereas $A$. acutifolius, having much stronger flavor, is used as a condiment in small quantities. This allows for a higher price of the spears, which ranges approximately between $\$ 9$ and $\$ 32$ per kilogram in Italy (i.e., two to four times the price of cultivated asparagus) depending on season and market.

The most important problem that has limited success in growing $A$. acutifolius has been that its seeds have a strong dormancy and do not germinate easily (Venezia et al., 1993). A suitable technique for production of transplants has been proposed (Rosati and Falavigna, 2000). Less information is available on field practices, yield potential, and labor requirements for cultivation and harvest. There is only one paper on yields and field techniques for wild asparagus (Rosati et al., 2005), but the study was limited to one area of southern Italy and to one ecotype. Because no selected varieties of A. acutifolius exist, the only material available for cultivation is represented by seeds from local populations, which are genetically variable and can be distinguished on a molecular basis (Aceto et al., 2002). Ecotypes might not adapt to environments different from the one of origin.

The evergreen and prickly vegetation poses an obstacle to fast and comfortable harvesting. Cutting the vegetation to ease harvest reduces harvest labor by approximately half but may reduce plant vigor and yield and compromise plant longevity (Rosati et al., 2005); however, these authors suggest that with better plant nutrition and care and suspending harvest earlier, such an effect should be overcome.

In the present work, we report the field techniques used for and the yield obtained from the cultivation of two wild asparagus ecotypes planted at two different spacings in central Italy. Additionally, we measured labor requirements for harvest to provide some data for an economic evaluation of the crop.

\section{Materials and Methods}

The field trial was initiated in 2001 at the Experimental Station of the Department of Agricultural and Crop Sciences, University of Perugia, located in central Italy $\left(43^{\circ} \mathrm{N}, 165\right.$ $\mathrm{m}$ ASL) on a clay-loam soil with $1.3 \%$ o.m. and medium contents of available $\mathrm{P}$ and exchangeable $\mathrm{K}$.

In a factorial design with four replicates as randomized blocks, two ecotypes of wild asparagus (Asparagus acutifolius L.) and two crop densities were compared. One ecotype was local, from the Perugia province, 
central Italy, and the other was from the Salerno province, southern Italy. The two crop densities, 3.1 and 5.0 plants $/ \mathrm{m}^{2}$, were obtained with rows $0.80 \mathrm{~m}$ apart and withinrow spacing of 0.40 and $0.25 \mathrm{~m}$, respectively.

Each plot consisted of six rows with 14 plants per row resulting in a plot area of $\approx 25 \mathrm{~m}^{2}$ in the $3.1 \mathrm{plant} / \mathrm{m}^{2}$ density and in $\approx 16 \mathrm{~m}^{2}$ in the 5.0 plant $/ \mathrm{m}^{2}$ density.

The crop was planted on 12 Oct. 2001 using 1-year-old bare-root plants complete with the evergreen aerial part and the underground crowns. Plants and crowns were not homogeneous in size, ranging from $\approx 20$ to $60 \mathrm{~g}$ of fresh weight, so they were screened to assure the highest intrablock homogeneity and reduce experimental error. Plants that died in the next two growing seasons were replaced in Nov. 2002 and 2003. Plants that died later were not replaced.

The soil was fertilized before planting with $50 \mathrm{t} \cdot \mathrm{ha}^{-1}$ of cow manure. In the following years, either mineral fertilizer at the end of winter or chicken manure after harvest were broadcast for a total of $\approx 50$ to 70 $\mathrm{kg} \cdot \mathrm{ha}^{-1} \mathrm{~N}$ per year. The crop was irrigated once or twice a year during the driest periods (July and August) with $\approx 30 \mathrm{~mm}$ of water per irrigation distributed by drip (first 2 years) or sprinkle (following years) irrigation.

The crop was mulched with $\approx 7 \mathrm{~cm}$ of straw annually renewed except in 2005. Mulching helped with weed management, which was done by hand removal before harvest. After harvest, weeds were not controlled and developed with the crop. Because hand removal of weeds is costly, in 2005, weeds were not controlled and, in 2006, they were suppressed before harvest by mowing them together with the prickly asparagus vegetation and then by hand-spraying glyphosate between rows before spear emergence, carefully avoiding the rows in case the crop could absorb the chemical through the cut stems.

Harvest began in 2004, because plants were small and produced small spears in the years previously. For the same reasons, the 2004 harvest was limited to a short period (i.e., six times over a period of 1 month) and the data were not included in this study. In 2005 and 2006, spears were harvested at regular intervals for longer periods: nine times between 30 Mar. and 15 May in 2005

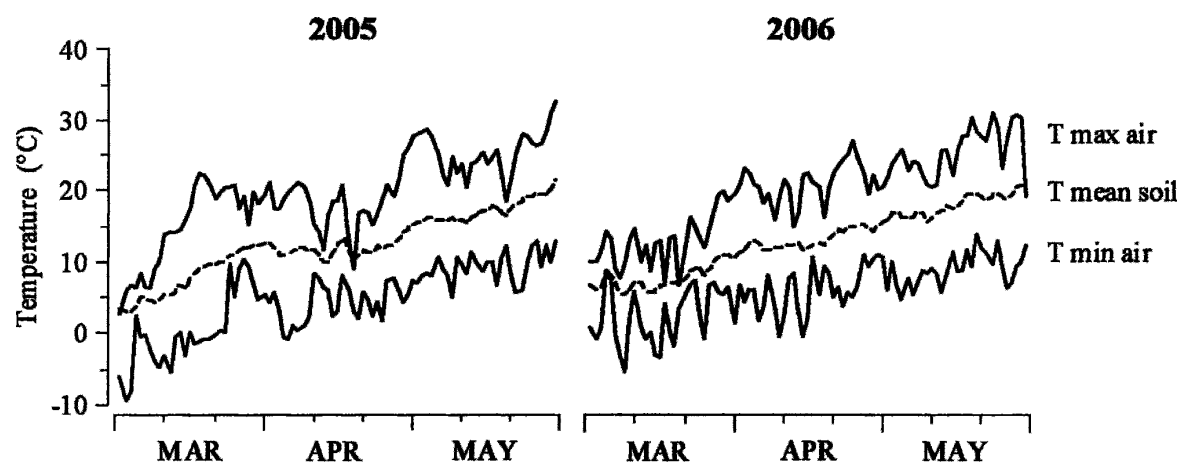

Fig. 1. Minimum and maximum air temperature and mean soil temperature during the harvest season of 2005 and 2006.

and eight times between 3 Apr. and 11 May in 2006. The shorter harvest period in 2006, compared with 2005 , was planned to reduce the stress to the crop deriving from having removed all the evergreen vegetation before harvest as previously suggested (Rosati et al., 2005). In addition, three spears were left unharvested in the last harvest of 11 May 2006 , removing only spears in greater number. To avoid border effects, only spears from the four central rows in each plot were used to assess yield and quality parameters.

Only spears taller than $30 \mathrm{~cm}$ were harvested leaving the remainder of them for the next harvest, and spear number and fresh weight were determined for each harvest. Additionally, in 2006, fresh and dry weight (after desiccation at $100{ }^{\circ} \mathrm{C}$ for $48 \mathrm{~h}$ ) and length of the edible (i.e., tender) part and waste (i.e., fibrous) part of 10 spears per replication were measured together with spear diameter at the base. The edible part was defined as the part that snapped easily by hand when the spear was bent, whereas the part that bent without breaking was considered waste.

In 2006, the percentage of plants that had died was calculated for each plot.

Data were analyzed by analysis of variance using the $\mathrm{R}$ program ( $\mathrm{R}$ Development Core Team, 2005).

\section{Results and Discussion}

Temperature conditions for field trials. Minimum and maximum air temperature as well as mean soil temperature during harvest of both years are shown in Figure 1. March of both years was characterized by low minimum temperatures, several degrees below freezing, which delayed the first harvest to the end of March in 2005 and to the beginning of April in 2006. Normally, the first harvest is expected a few days before the end of March in the area of the field site. In 2006, minimum temperatures dropped below freezing a couple of times in mid-April, damaging some spears.

Spear yield. The yield in fresh spears was unaffected by either genotype or plant density in 2005 (Table 1) or 2006 (Table 2) and was $1307 \mathrm{~kg} \cdot \mathrm{ha}^{-1}$ in 2005 and $1186 \mathrm{~kg} \cdot \mathrm{ha}^{-1}$ in 2006. These figures are in agreement with yields recorded in other field experiments on $A$.

\section{6}

acutifolius carried out in southern Italy (Rosati et al., 2005). The Perugia ecotype was consistently more productive in both years (i.e., $\approx+34 \%$ in 2005 and $+30 \%$ in 2006), but the difference was not statistically significant $(P=$ 0.16 for 2005 and $P=0.15$ for 2006), probably as a result of heterogeneous plant age and size within blocks introduced by replacing dead plants in 2002 and 2003.

In 2006, spear emergence was more abundant at the beginning of the harvest season; cumulated spear yield for the first three harvests was approximately double in 2006 (i.e., $\approx 600 \mathrm{~kg} \cdot \mathrm{ha}^{-1}$ in $2006 \mathrm{vs}$. $\approx 300 \mathrm{~kg} \cdot \mathrm{ha}^{-1}$ in 2005) despite lower temperatures. This more abundant early emergence of spears was probably stimulated by the vegetation removal before harvest in 2006 .

The percentage of plants that had survived at the beginning of 2006, which does not account for the plants replaced in 2002 and 2003, was not statistically different among treatments and the field average was $85 \%$. Because the replacement of dead plants in 2002 and 2003 had been necessary mainly in the third and fourth block with no differences among treatments, we assumed that mortality was mainly related to an unsuccessful establishment of weak (i.e., small-sized) transplants. Considering that the most productive plots in all treatments were in the first or second block (i.e., those transplanted with bigger plants), we speculate that the yield from the best plot represents an estimate of the yield that could have been obtained by using good-quality transplants. This was, on average, $46 \%$ greater than the actual average yield over the four replicates. This yield could be even higher considering that even in the best plots, $\approx 15 \%$ of the plants were missing and that row spacing could probably be reduced down to $0.6 \mathrm{~m}$ (Rosati et al., 2005). Further research is needed to confirm this speculation.

The percentage of plants surviving at the beginning of 2006 allowed the calculation of the yield (i.e., number and weight of spears) per plant (Table 3). This was significantly affected by plant density, whereas the genotype effect was nonsignificant. Increasing plant density from 3.1 to 5.0 plants $/ \mathrm{m}^{2}$ significantly reduced total fresh weight of spears per plant by approximately one-third. The reduction was the result of a proportional and statistically significant decrease in spear number, whereas average spear weight was unaffected. Similar results were obtained in other field experiments in which spear number decreased with vegetation removal before harvest, whereas average spear weight was unaffected (Rosati et al., 2005). This might result from the limited ability of wild asparagus genotypes, unlike $A$. officinalis cultivars, to increase spear diameter in response to abundant reserves. Because spear height was uniformly determined by harvesting, increasing spear emergence remained the only outlet for the plant to spend reserves.

The nonsignificant effect of plant density on yield per hectare (Tables 1 and 2) resulted from the greater number of plants per unit 
Table 1. Yield (total and at each harvest date) in 2005 for two ecotypes of wild asparagus (ecotypes from the provinces of Perugia and Salerno) planted at two densities $\left(3.1 \text { and } 5.0 \text { plants } / \mathrm{m}^{2}\right)^{2}$

\begin{tabular}{|c|c|c|c|c|c|c|c|c|c|c|c|}
\hline \multirow[b]{2}{*}{ Ecotype } & \multirow{2}{*}{ 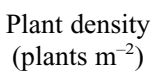 } & \multirow{2}{*}{$\begin{array}{l}\text { Total yield } \\
\left(\mathrm{kg} \cdot \mathrm{ha}^{-1}\right)\end{array}$} & \multicolumn{9}{|c|}{ Yields on each harvest (\% of total) } \\
\hline & & & $3 / 30$ & $4 / 8$ & $4 / 14$ & $4 / 20$ & $4 / 26$ & $5 / 2$ & $5 / 6$ & $5 / 10$ & $5 / 15$ \\
\hline Perugia & 5.0 & 1574 & 7.0 & 6.0 & 11.0 & 16.0 & 9.0 & 16.0 & 17.0 & 9.0 & 8.0 \\
\hline$P$ & & NS $(0.87)$ & & & & & & & & & \\
\hline \multicolumn{12}{|c|}{ Average per ecotype } \\
\hline Perugia & & 1495 & 7.0 & 6.0 & 11.0 & 16.0 & 9.0 & 15.0 & 18.0 & 10.0 & 8.0 \\
\hline \multicolumn{12}{|c|}{ Average per density } \\
\hline 3.1 & & 1207 & 7.0 & 6.0 & 10.0 & 16.0 & 9.0 & 17.0 & 18.0 & 10.0 & 8.0 \\
\hline 5.0 & & 1407 & 7.0 & 6.0 & 10.0 & 16.0 & 9.0 & 17.0 & 18.0 & 9.0 & 8.0 \\
\hline$P$ & & NS $(0.43)$ & & & & & & & & & \\
\hline Average of field & & 1307 & 7.0 & 6.0 & 10.0 & 16.0 & 9.0 & 17.0 & 18.0 & 10.0 & 8.0 \\
\hline $\mathrm{SE}$ & & 24.4 & 2.0 & 1.7 & 1.1 & 1.7 & 1.3 & 1.3 & 1.8 & 1.0 & 1.4 \\
\hline
\end{tabular}

${ }^{\mathrm{z}}$ Neither ecotype nor plant density had significant effects. The probability $(P)$ values are shown in brackets.

${ }^{\mathrm{Ns} N o n s i g n i f i c a n t .}$

Table 2. Actual yield (total and at each harvest date) and potential yield in 2006 for two ecotypes (ecotypes from the provinces of Perugia and Salerno) of wild asparagus planted at two densities $\left(3.1\right.$ and 5.0 plants $\left./ \mathrm{m}^{2}\right){ }^{\mathrm{z}}$

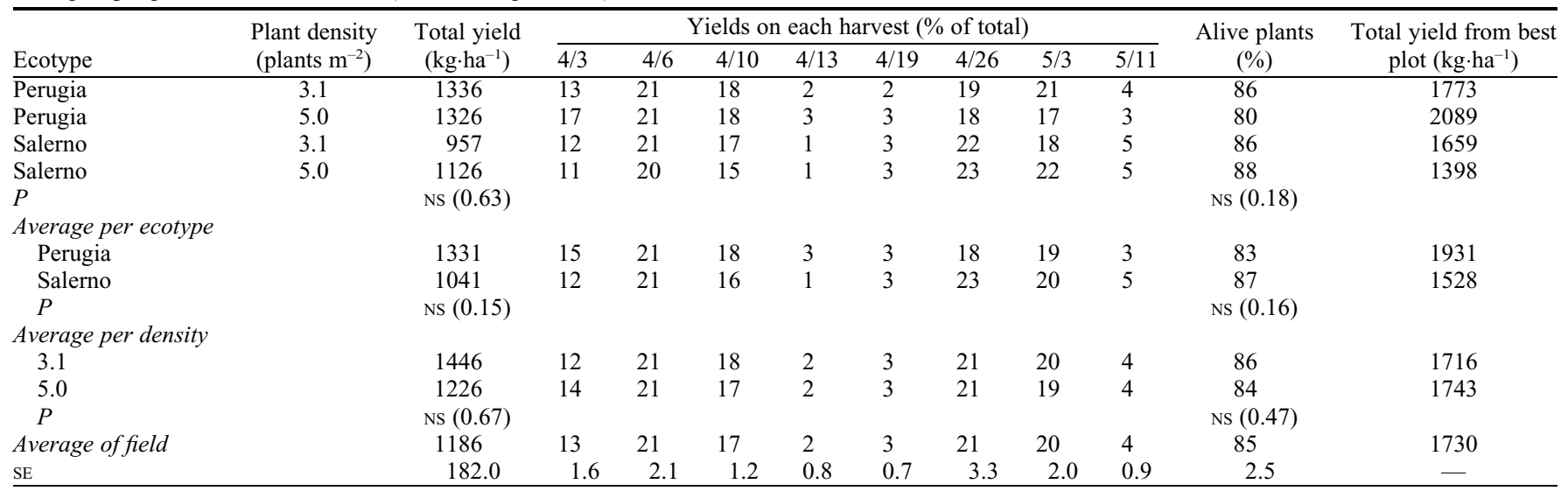

${ }^{\mathrm{z}}$ Neither ecotype nor plant density had significant effects. The probability $(P)$ values are shown in brackets.

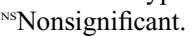

Table 3. Yields and number of spears per plant, and average spear weight in 2006 for two ecotypes (ecotypes from the provinces of Perugia and Salerno) of wild asparagus planted at two densities (3.1 and 5.0 plants $\left./ \mathrm{m}^{2}\right)^{\mathrm{z}}$

\begin{tabular}{lcccc}
\hline Ecotype & $\begin{array}{c}\text { Plant density } \\
\left(\text { plants } \mathrm{m}^{-2}\right)\end{array}$ & $\begin{array}{c}\text { Total yield } \\
\text { per plant }(\mathrm{g})\end{array}$ & $\begin{array}{c}\text { Total spears } \\
\text { per plant }(\mathrm{n})\end{array}$ & $\begin{array}{c}\text { Avg spear } \\
\mathrm{wt}(\mathrm{g})\end{array}$ \\
\hline Perugia & 3.1 & 46.0 & 8.0 & 5.8 \\
Perugia & 5.0 & 30.3 & 5.3 & 5.8 \\
Salerno & 3.1 & 32.3 & 5.8 & 5.6 \\
Salerno & 5.0 & 24.0 & 4.0 & 6.0 \\
$P$ & & NS $(0.48)$ & NS $(0.63)$ & NS $(0.90)$ \\
Average per ecotype & & & & \\
$\quad$ Perugia & 38.1 & 6.6 & 5.8 \\
$\quad$ Salerno & 28.1 & 4.9 & 5.8 \\
$P$ & & NS $(0.08)$ & NS $(0.11)$ & NS $(0.97)$ \\
Average per density & & & & \\
$\quad 3.1$ & & 39.1 & 6.9 & 5.7 \\
5.0 & & $* 7.1$ & 4.6 & 5.9 \\
$P$ & & 33.1 & $*(0.05)$ & $*(0.90)$ \\
Average of field & & 5.12 & 5.8 & 5.8 \\
SE & & & 1.00 & 0.51 \\
\hline
\end{tabular}

${ }^{2}$ The probability $(P)$ values are shown in brackets.

${ }^{\mathrm{Ns} N o n s i g n i f i c a n t ;}$ *statistically significant.

of land area, which compensated for the decreased production of individual plants (Table 3).

Spear quality parameters. Spear quality was unaffected by either genotype or plant density in 2006 (Table 4). Spear fresh weight $(5.7 \mathrm{~g})$, height $(35.8 \mathrm{~cm})$, basal diameter between Tables 3 and 4 derives from the different sample size; in Table 3, total yield was divided by total spear number, whereas Table 4 reports data for 10 sampled spears per plot. The lower variability in spear average weight in Table 4, despite the lower number of spears sampled, derives from the fact that the 10 spears sampled for quality parameters were carefully cut at $30 \mathrm{~cm}$, whereas the length of the remaining spears was determined more by the harvesting crew.

The average weight of spears was very similar to that reported by Rosati et al. (2005), whereas for the other parameters, there are no previous reports in the literature.

Economic approach of the crop. The hand labor productivity for harvesting was $1.2 \mathrm{~kg}$ of spears per hour in 2005 when the asparagus vegetation was not removed before harvest and $\approx 3 \mathrm{~kg}$ per hour in 2006 when the vegetation was removed (data not shown). The amount of spears harvested per hour of labor was lower (i.e., approximately half) than previously reported (Rosati et al., 2005). The difference in these findings suggests that more data are needed to understand the actual labor requirements under various growing conditions. However, even using our more conservative numbers, labor requirements for 
Table 4. Quality parameters in 2006 for two ecotypes (ecotypes from the provinces of Perugia and Salerno) of wild asparagus planted at two densities (3.1 and 5.0 plants $\left.\mathrm{m}^{-2}\right)^{\mathrm{z}}$

\begin{tabular}{|c|c|c|c|c|c|c|c|}
\hline Ecotype & $\begin{array}{l}\text { Plant density } \\
\left(\text { plants } \mathrm{m}^{-2} \text { ) }\right.\end{array}$ & Spear wt (g) & Spear ht $(\mathrm{cm})$ & $\begin{array}{l}\text { Spear diam } \\
(\mathrm{mm})\end{array}$ & $\begin{array}{l}\text { Length of edible } \\
\text { portion ( } \% \text { of } \\
\text { total length) }\end{array}$ & $\begin{array}{l}\text { Wt of edible } \\
\text { portion ( } \% \text { of } \\
\text { total wt) }\end{array}$ & $\begin{array}{c}\text { Spear dry matter } \\
\text { content }(\%)\end{array}$ \\
\hline Perugia & 3.1 & 5.7 & 36.3 & 5.0 & 42.3 & 36.3 & 15.1 \\
\hline Perugia & 5.0 & 5.7 & 35.4 & 4.8 & 43.3 & 36.8 & 15.4 \\
\hline Salerno & 3.1 & 5.7 & 35.7 & 4.7 & 47.0 & 36.8 & 15.1 \\
\hline Salerno & 5.0 & 5.7 & 36.0 & 4.7 & 44.3 & 38.3 & 14.8 \\
\hline$P$ & & NS $(0.90)$ & NS $(0.22)$ & NS $(0.67)$ & NS $(0.49)$ & NS $(0.40)$ & NS $(0.36)$ \\
\hline \multicolumn{8}{|c|}{ Average per ecotype } \\
\hline Perugia & & 5.7 & 35.8 & 4.9 & 42.8 & 36.5 & 15.3 \\
\hline Salerno & & 5.7 & 35.8 & 4.7 & 45.6 & 37.5 & 14.9 \\
\hline$P$ & & NS $(0.97)$ & NS $(0.98)$ & NS $(0.22)$ & NS $(0.29)$ & NS $(0.11)$ & NS $(0.33)$ \\
\hline \multicolumn{8}{|c|}{ Average per density } \\
\hline 3.1 & & 5.7 & 36.0 & 4.9 & 44.6 & 36.5 & 15.1 \\
\hline 5.0 & & 5.7 & 35.7 & 4.7 & 43.8 & 37.5 & 15.1 \\
\hline$P$ & & NS $(0.90)$ & NS $(0.48)$ & NS $(0.48)$ & NS $(0.74)$ & NS $(0.11)$ & NS $(0.48)$ \\
\hline Average per field & & 5.7 & 35.8 & 4.8 & 44.2 & 37.0 & 15.1 \\
\hline SE & & 0.28 & 0.40 & 0.17 & 2.58 & 0.57 & 0.34 \\
\hline
\end{tabular}

${ }^{\mathrm{z}}$ The probability $(P)$ values are shown in brackets.

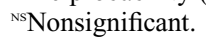

wild asparagus harvest would be $1250 \mathrm{~h}$ per hectare (i.e., assuming yields of 1.5 tons per hectare) without removing the vegetation or $500 \mathrm{~h}$ removing it. Harvesting is therefore a very expensive practice. Hypothesizing $500 \mathrm{~h}$ per hectare (i.e., cutting the vegetation before harvest), a sale price of $10 €$ per kilogram of spears and a cost of $10 €$ per hour of labor, harvest cost would represent one-third of the crop's gross income. Even with more conservative numbers, the crop should easily pay for the labor, which might represent an opportunity of self-employment in small farms or in rural marginal areas. Alternatively, the spears could be harvested directly by the consumers in pick-your-own operations associated with tourism.

Although the harvest efficiency of labor appeared lower than previously reported, the increased efficiency with vegetation removal before harvest was in agreement with previous findings in which harvest efficiency was doubled (Rosati et al., 2005). These authors found that cutting the vegetation reduced plant vigor and longevity but suggested that better irrigation and nutrition as well as interrupting harvest earlier should allow the plant to recover from the stress of having to replace the evergreen vegetation. Further work is needed to assess whether these practices are sufficient to prevent the loss of plants or plant vigor associated with vegetation removal.

\section{Conclusions}

After 5 years of cultivation, including 2 years of harvest, the wild asparagus appeared suitable for cultivation. The spear yield, as a field average, was $1307 \mathrm{~kg} \cdot \mathrm{ha}^{-1}$ in 2005 and $1186 \mathrm{~kg} \cdot \mathrm{ha}^{-1}$ in 2006 when harvest was interrupted earlier and $\approx 15 \%$ of plants were missing. As a result of the heterogeneity of the plant materials at the onset of the crop, some blocks were less productive than others, lowering average yields. Thus, with good plant material and appropriate field practices, it appears that greater yields should be easily reachable.

Because plant density between 3.1 and 5 plants $/ \mathrm{m}^{2}$ did not affect yield and spear quality, the ideal plant density should be chosen considering the cost of transplants and that of replacing dead plants in the following years; the latter operation might not be necessary with high densities given that yield loss from dead plants can be compensated for by nearby plants.

The two ecotypes tested here did not differ significantly in any parameter, although the high variability might have masked a possible difference in favor of the local (i.e., Perugia) ecotype. Labor requirements for harvest should be on the order of $500 \mathrm{~h}$ per hectare ( $3 \mathrm{~kg}$ of spears per hour) if the prickly vegetation is removed before harvest, but the long-term effect of such practice on plant vigor and mortality, even with due care to interrupt harvest at an earlier time, remains to be assessed.

\section{Literature Cited}

Aceto, S., A. Parente, G. Aliotta, A. Rosati, and L. Gaudio. 2002. Utilizzazione della tecnica RAPD-PCR per l'analisi della biodiversità in popolazioni di Asparagus acutifolius L. Italus Hortus 9:49-52.
Adam, D. 2004. L'asperge sauvage: De la recolte spontanee a une production commerciale. Infos-Ctifl 207:43-45.

Aliotta, G., S. Aceto, A. Farina, L. Gaudio, A. Rosati, M. Sica, and A. Parente. 2004. Natural history, cultivation and biodiversity assessment of asparagus. In: Global Research-Network. (Ed.): Research Advances in Agriculture and Food Chemistry.

Bozzini, A. 1959. Revisione cito-sistematica del genere Asparagus. Caryologia 12:199264.

Della, A., D. Paraskeva-Hadjichambi, and A.C. Hadjichambis. 2006. An ethnobotanical survey of wild edible plants of Paphos and Larnaca countryside of Cyprus. Journal of Ethnobiology and Ethnomedicine 2:34.

Fiori P. P., Giola M., Ledda M., Tedde M., 2001. Valorizzazione dell'asparago selvatico (A acutifolius L.). L'Informatore Agrario 50:47.

Pieroni, A. 2005. Food for two seasons: Culinary uses of non-cultivated local vegetables and mushrooms in a south Italian village. Int. J. Food Sci. Nutr. 56:245-272.

R Development Core Team. 2005. R: A language and environment for statistical computing. $\mathrm{R}$ Foundation for statistical computing, Vienna, Austria, ISBN 3-900051-07-0. 3 May 2007. $<\mathrm{http}: / /$ www.r-project.org $>$.

Rosati, A. 2001. Un possibile futuro per 1'asparago selvatico. L'Informatore Agrario 7:89-92.

Rosati, A. and A. Falavigna. 2000. Germinazione dei semi di asparago selvatico. L'Informatore Agrario 56:53-55.

Rosati A., Pepe R., Senatore A., Perrone D., Falavigna A., 2005. Produttività dell'asparago selvatico. L'informatore Agrario 8: $75-77$.

Venezia, A., G.P. Soressi, and A. Falavigna. 1993. Aspetti relativi alla valorizzazione di specie di asparago spontanee in Italia. Agricoltura e Ricerca 141:41-48. 